\title{
Government Policy Functions on The Supporting Aspect of Mineral Resources Management and Post Retail in Stipulation of Act No. 23 of 2014
}

\author{
Suryaningsi ${ }^{1}$ \\ \{ suryaningsih.kmd@gmail.com ${ }^{1}$ \} \\ Lecturer of FKIP UNMUL, Samarinda, Indonesia ${ }^{1}$
}

\begin{abstract}
The purpose of the study is to describe the function of supervision in the system of government in the region after the change to Law no. 23 of 2014 on the management of mineral and coal resources. The type of research used is normative legal research. With analytic descriptive type aimed at explaining about State Policy Function on supervision aspect by Inpektor Tambang for mineral and coal resource management. Data collection techniques through observation, interview and documentation. Analyzed by using a resistance that conveyed Miles and Huberman. The results and discussion on the function of government policy on the management of mineral resources and coal post in Law No. 23 of 2014 on local government in review of the supervision aspect is not running as expected in Law No. 4 of 2009 Mineral and Coal Mining. This is due to constraints with infrastructure and facilities in the form of budget, as well as instructions from the KPK and BPKP so that guidance and supervision runs on a budget basis, given the very challenging mining field.
\end{abstract}

Keywords: Good gavernance, Policy, Utilization, and Justice.

\section{Introduction}

While still in the implementation of Law no. 32 of 2004 Regarding local governance, the supervisory function runs even though it has not reached the optimal target due to limited personnel who will act as supervisor (mining inspector) can be further called IT. Superintendent Inspector who has attended the IT training and passed as many as 899 people, although the actual government target of 1000 people but empirically functioning only 102 people. allegedly there is a deviation of IT procurement budget and the functioning of IT posttraining as a trigger of uncontrolled management and exploitation of mineral and coal resources, which impact on the state of theft and also as a result of the stipulation of Law no. 23 of 2014 on the system of Regional Government without going through socialization.

The legal basis of IT task and function can be seen in Law no. 4 of 2009 on Mineral and Coal Mining. The lack of optimization of the function of IT based on minerba mining regulations, causing problems in mining management more complicated, which is also caused by the role of regents and mayors that dominate so that the sale of licensing in the area occurred. And this is increasingly happening thus there is a suspicion that there is a tendency of dick and coaching from the center also does not go as expected. One side of the KPK found that there is a huge but very low-cost IT procurement budget, the KPK's findings reinforce the government's intention to issue regulations no. 23 of 2014. Therefore, through the above 
phenomena and issues the authors would like to examine and describe the function of government policy towards implementation of supervision and guidance of Kepasca in Law No 23, 2014 on Regional Government,

\section{Research Methods}

The type of research used is normative legal research. With an analytical descriptive type aimed at explaining the State Policy Function on the supervision aspects of mineral and coal resource management.

In describing the variables in this study contained therein indicators as part of a scientific search effort that will be described and analyzed by using the following approach: The philosophy approach is to know the role of East Kalimantan provincial government in memknai and implement the regulation of management of mineral and coal resources. The approach used is the conceptual approach (conceptual approach), namely by moving the views and doctrines that developed in the science of law so that can be found a new idea and the principles relevant to the problem under study. Approach in the Law (Statute approach) and Concept Approach (Concept approuch).

The legal substances used in this study consist of; primary, secondary and tertiary legal materials. The primary legal materials are laws and regulations relating to violence against women and children and their implementing regulations. Secondary legal materials in the form of legal literature related to the management of coal mining, legal materials obtained from the internet, seminar results, research results, symposia and results of workshops related to the object of research. While tertiary legal material that is supporting documents, such as statistical data and monographs and other similar.

\section{Result And Discussion}

After the enactment of Law No. 23 of 2014 on Regional Government, the management of IT becomes the authority of the Central Government c.q KESDM. Currently the East Kalimantan Provincial Government has 58 civil servants (PNS) in the ESDM sector who have been appointed to the Mine Inspector. The 58 who experienced the transfer process from the District / City including those from the province alone which amounted to seven people so that the overall total reached 58 people IT. This guidance and supervision is conducted on all minerba mining business actors together with the Provincial Government, Regency / Municipal Government, Holders of Mining Business Licenses, and other related parties in East Kalimantan.

The guidance and supervision in IT regulation is arranged based on Article 141 paragraph (2) of Law No. 4 Year 2009 on mineral mining, that supervision conducted by IT is among others: technical supervision, conservation supervision, supervision of OSH, supervision of mining operation, supervision of environmental management life, post-mining reclamation, supervision of the mastery of mining technology. In addition, minerba regulations decrease Government Regulation no. 55 Year 2010 on Guidance and Supervision then through the PP which explains related to mining technical. Mentioned in Article 36, "Supervision of the Mine Inspector is done through; Evaluate reports, periodic checks, and assessments of the success of conducting activities. 
The mechanism of implementation of supervision as follows:

Initially starting from the planning of supervision (Work Plan) which is of course compiled in advance, just running, So for example implementation in 2017 then the preparation of work plan including budget issues carried out in 2016. Once approved budget plan and its implementation then carried out supervision.

Associated with SOPs or work guidelines prior to conducting supervisory activities in the field, first write to the company including the names that will conduct supervision as well as the timing of the implementation of activities how many days must be listed.

Before conducting surveillance, first learn what related documents should be supervised then do the monitoring. For example, the implementation of environmental monitoring, of course, the IT study document implementation report, management, and environmental monitoring. After the study and then doeksekusi spaciousness, then the process of supervision. The results of field supervision activities in pour in the form of reports of results of supervision activities; what his findings, what suggestions. If in the Mining Inspector important things are written in the book mine, the time of its implementation when, the completion of when. Subsequently reported to the head of the supervisory activities.

After reporting, then create a letter again to the relevant company related to the results of follow-up surveillance. For the types of surveillance performed are:

1. Administration supervision is to evaluate the reports.

a) Direct supervision or spaciousness, be it inspection of routine routine

b) Examination such as environmental monitoring, case finding.

c) Testing is testing technology tools used mining companies.

2. Inspection is a planned supervision usually once every three months, six months, and once a year. Depending on the budget made in accordance with the work plan. If in the Inspection rules implemented once a year.

3. Inspection is an unplanned supervision, if there are reports, complaints, we are directly down the spaciousness. Especially for the examination does not first with the letter no what. Unplanned meanings are not scheduled so that time can go down if there is a complaint report. At most we only tell via via sms if it will do the checking.

Reports from the public prihal environmental damage can also be reported to KEDM if true there are findings can be directly sent to the department that the community environment there are case findings. Well therefore the head of the service will officially assign us, but nature emergency for example we die immediately dive accidental field if it is accidental.

Article 33 Paragraph (3) of the 1945 Constitution of the Republic of Indonesia, determining the earth and water and natural resources contained therein are controlled by the state and used for

the greatest prosperity of the people. The connection with the implementation of local government oversight is already in line with Law no. 23 Year 2014 which mengahapuskan authority District / City. This is in line, because in essence the oversight remains and is not removed because the management needs to be supervised, both administratively and in the field. Assuming the management of natural resources contained in law 23 including licensing is withdrawn to the province, I think one of the factors of service is also the supervision. And it ultimately needs adjustment, but I think the future can be better.

The mandate of Article $28 \mathrm{H}$ paragraph (1) of the 1945 Constitution of the Republic of Indonesia contains the meaning that a good and healthy environment is the right of every citizen. In line with the presence of Law no. 23 of 2014 in connection with the government oversight function. For now it has not run yet, but in the future hope can be effective because that rule has been run for three years. But for environmental monitoring activities not only the 
Mining Inspector, there are also environmental agencies, they also have environmental supervisory officials, they have an important role in implementing Article $28 \mathrm{H}$.

The existence of districts / municipal authority over the management of mineral resources as regulated in Law no. 4/2009 on Minerba, and one side of Law no. 23 of 2014, that the district / city authorities have been abolished. UU no. 4 year 2009, related to supervision supervision, supervisory authority is the responsibility of the minister of KESDM, in the Article stipulated that "the minister can delegate to the governor the authority of supervision". meaning the central government authority is in the Minister. Cuman indeed ultimately need a revision of the law. Because the article / rule of interpretation rules each person is different.

After being enacted by Law No. 23 of 2017, supervision activities remain, but as IT status is withdrawn into a central employee and remains in the province. The constraints that occur are about the budget. Budget issues impact on facilities and infrastructure and performance of bimwas (IT). The budget is indeed the responsibility of the province and for the year 2017 this is not budgeted 2018 possibly also does not exist. Because Kaltim suffered a deficit or a lack of budget. Under conditions such as those found to be ineffective from the performance of IT, this is justified by BPK and BPKP who advocate not to conduct surveillance activities without any budget. The presence of Law no. 23 Year 2014 Regarding local governance, does it cause problems with the oversight function of mineral and coal resource management.

In response to the post-conditions, initially it became a problem that is the problem of personnel switching, which lasted long enough, ranging from data collection, evaluation and until declared central employee takes a long time and is running less than perfect. Finally, what happens is contrary to the regulation if the IT policy is a central employee, but the rules of the game still use the provincial policy. for example status as a central employee but using the provincial budget. The meaning is related to the regulation and the like has not been related to the budget to be used, the budget from the regional employees from the center. Well this is the first time like this.

Staffing problems are clear, only in the implementation of central government needs / mendagri re-publish or add related rules. keterbuakaan or transparency of information in the management of mineral resources and coal from the company. Now can not be covered up again, let alone mining activities are open, easy access community, the company also if the cover-up even a little trouble. For now it is open for them to report, just maybe the distribution of information that needs to be seen, social media is a lot and easily accessible.

Constraints / obstacles encountered in performing supervisory functions as follows:

- Geographical factors (difficult to reach remote areas)

- There is no operational facilities and infrastructure. The amount of IT does not fit the place

- Operational budget

Efforts made are:

- Implementation of monitoring that can be done in the form of evaluation reports and case findings.

- Operational budgets, from ministries seeking and conducting evaluations, not many provinces have budgeted. Because it is still constrained rules, because the umbrella law that does not exist. While the accountability report of East Kalimantan Province IT become a problem.

- Infrastructure facilities, this effort continues to be lobbying

- Geographical location, there is currently no activity. Our initiative is still encouraging the provincial government to procure the budget for operations. Although located far away but if there is a budget is not a problem and we can reach. 
The coordination system of IT, companies, and local government, works well, because the Head of Department (KESDM) once a month holds regular meetings with companies, discuss some issues or coordination or provide input related to the implementation of mining management.

\section{Legal Certainty}

Various regulations at the local level, both in the form of regional regulations and regulations of regency / municipality heads, which regulate natural resources management that were originally their authority, should be reviewed and even revoked or declared invalid. This is important, in order to realize order and provide legal certainty. In contrast, the provincial and / or central government need to make new regulations as the basis or legal umbrella in the implementation of what is their authority in managing natural resources.

Legal certainty is needed by the company because in doing the mining other than subject to the provisions of the law as well as other related provisions and can not be released away. Legal certainty is that the consistency of regulations is indicated by the existence of nonconflicting regulations between one rule and another, and can be used as a guide for a sufficient period of time so as not to impress any change of officials is always followed by change of conflicting rules.

The response of the company in the management of the licensing there is a lack of synchronization between the policy of the director general with the ministry of ESDN East Kalimantan Province, an experience when the processing of shipping licenses in charge and dance while the company knows that the policy of the director general does not regulate the collection, because a policy then, by the company even though in the sense of unclear and until now the budget is manifested cause unclear.

Responding to conditions above the law or supremacy of the law is very important, to realize the true law and equitable justice. Thus the manifestation of legal certainty according to Soerjono Soekanto is as follows: is the regulations of the central government generally accepted throughout the country. Another possibility is that the rule is generally accepted, but only for certain groups. In addition, local regulations can also be made by local authorities that apply only in the regions, such as municipal regulations.

Based on the above description it is clear that the role of law in creating a conducive investment climate is an absolute requirement, since investors will not invest in places that do not have legal certainty this can lead to a very high legal risk.

As expressed by PT. Indominco Mandiri in Kutim regency that people do demo because they want to use Indominco Mandiri road for public transportation truck. As well as the various demands of society on the company in this foundation the company felt uncomfortable and needed legal certainty of the government.

Basically, the obligation of the local government is to ensure the certainty and security of the business for the execution of the bans. To ensure the certainty and security, it is necessary to regulate the authority of the government, provincial and district / municipality in the implementation of clear mining. The current condition of the province of East Kalimantan is that the regional government has not been able to provide security for the investors of both foreign investors and domestic investors to develop business in the region. Some things that haunt miners in East Kalimantan have not been answered, namely legal certainty and security guarantees, supporting infrastructure conditions, and ulayat land rights. Whereas a conducive investment climate can increase economic activity, both large scale and economic activities populist. 
The existence of legal certainty is a hope for justice seekers against the arbitrary actions of law enforcement officers who are sometimes always arrogance in performing their duties as law enforcement. Because with legal certainty the company will know the clarity of rights and obligations according to law. Without legal certainty, people will not know what to do, not knowing whether his actions are right or wrong, prohibited or not prohibited by law. This legal certainty can be manifested through a good and clear normation in a law and will be clear to its application. In other words, the certainty of the law means the exact law, the subject and the object and the threat of the law. However, legal certainty may not be considered an absolute element at all times, but the means used in accordance with the situation and conditions with due regard to the principle of benefit and efficiency. This is in line with the theory of good governance that put forward by G.H Addink, related to the activities of the implementation of functions to organize the public interest. good governance regarding the implementation of three basic tasks of the government are:

first, to guarantee the security of all persons and the society itself (the guarantor of the security of everyone and society). Second, to manage an efective frame work for the public sector, the private sector, and civil society (managing an effective structure for the public sector, the private sector, and society). And thirdly, to promote economic, social and other aims in accordance with the wishes of the population (advancing economic, social and other objectives with the will of the people). In realizing the G.H Addink theory, it is necessary to synergize through the effort of principle of certainty (principle of legal certainty, which is the main principle in implementing good governance.

The explanation of the government's policy on mineral and coal mining management aspects After the Law No. 23 of 2014 on Regional Government is stipulated that the aspects of Licensing, Development and Supervision, Facilities and Certainty are needed for National stability. Mining Mining Management is a National Strategy that affects the state revenue and also has implications for the welfare and prosperity of the people. According to Carl I. Friedrick Policy as a series of actions proposed a person, group or government in a particular environment, with threats and opportunities that exist. The proposed policy is aimed at exploiting the potential as well as overcoming the existing obstacles in order to achieve certain goals.

This is where the role of government to be able to act firmly against the mining aspect of minerba, as the main potential revenue of the state. Arrangements and policies as defined in the Constitution of Article 33 paragraph 3 of the 1945 Constitution of the Republic of Indonesia set that: "The earth and the water and the natural resources contained therein shall be controlled by the State and used for the greatest prosperity of the people". It is very clear that if the minerba management takes place under the applicable regulations, there is a firm policy of government, good management and rightly managed through the licensing system accompanied by continuous guidance and supervision, the goal to create the greatest prosperity of the people can be realized. This is in line with the theory of justice according to Theory Mixed Economic Systim. which was put forward by W. Friedman. "mixed economy" is a variety of ways in which state power is used to control or supervise the country's economic system, although the economy is run by private companies. W. Friedman argues that the four functions of the state in a mixed economic system, namely: a. Function State as a "Regulator" State Function As "Entrepreneur" d) State Function As "Umpire" Conditions in Indonesia if it refers to Provider's principle that which guarantees the survival of society within a country is so that the concept of welfare state can be implemented in the form that the state not only acts as night watchman or security guard, night watch, but also able to guarantee the survival of the society substantially so that people can feel stable life without feeling any 
anxiety.Regulator conditions, the role of the government is to make regulations to create order, orderliness, security in the life of the state.Rules can be realized by the existence of mutual coordination, synergy and harmony between the government and the raktat, the responsibility of government in the management of natural resources for the welfare of the people.

The condition of Entrepreneurs, who state that the state as ruler $\mathrm{Cq}$. The government should act as an entrepreneur. Business actors on the management of mineral and coal resources within a state of power. But empirically it should be understood that mining has the following character, has a risk of basic, high technology, large capital. For conditions such as Indonesia the ability of capital to conduct business is still very much considering the capital in pengelolahan mining is like a parable to build a country that needs big capital. Strongly associated with high-risk characters, which means that in the management of minerals dragon minerba give goods in sacks, which is not clear the contents exist or not. This means that at the beginning of the work has been issued a large capital that does not necessarily have succeeded, so kerugiaan already absolute in preparing. Conditions like this, for the State of Indonesia, certainly not able, so that efforts can be done in the aspect of exploitation is to open a largescale investment. Therefore, this effort should be accompanied by strong regulation and placing the role of government higher than entrepreneurs.

High technology in the management of mineral and coal Mining is significant, that it is in the need of human resources who really have a specific science in minerba mining management, and in addition also requires infrastructure facilities with high technology.

Umpire Condition, Country Cq. The government becomes a referee or mediator, in the management of mining minerba, as an effort to realize as much as possible for the prosperity of the people.

The virtue of understanding the mixed economic system as proposed by W. Friedmant, the government has three important roles in overcoming the problems in the market economy system (free), namely:

1. Addressing inefficient allocation of resources, such as: monopolies, externalities, and public goods.

2. Addressing the distribution of uneven income.

3. Addressing macroeconomic issues, such as: inflation, unemployment, and economic growth.

Efforts to overcome the monopoly, the government issued a regulation that prohibits companies to monopolize and unfair business competition. In Indonesia this regulation is contained in Law Number 5 Year 1999 concerning the prohibition of monopolistic practices and unfair business competition.

- To overcome external costs (externalities), the government issued a regulation that prohibits pollution and environmental pollution. In Indonesia this regulation is contained in Article 21 of Law Number 5 Year 1984 regarding industry.

- To address the commercialization of public goods, the government provides education, transport and health facilities.

- To overcome the uneven distribution of income, the government imposes progressive tax rates, subsidies, and minimum wages.

- To overcome macroeconomic problems, the government provides stability by issuing macroeconomic policies (fiscal and monetary), and providing stimulus.

The economic system of democracy is an economic system aimed at realizing people's sovereignty in the economic field. This system is an economic system implemented in Indonesia. The role of the state in the people's economic system is: 
- Arranging the economy as a joint venture based on the principle of kinship; develop cooperation (Article 33 paragraph 1).

- Mastering the production branches that are important to the state and which affect the livelihood of the people; developing SOEs (Article 33 paragraph 2).

- Master and ensure the utilization of the earth, water and all the wealth contained therein for the greatest prosperity of the people (Article 33 paragraph 3).

- Managing the state budget for the welfare of the people; impose a progressive tax and subsidize.

- Maintain monetary stability.

- Ensure that every citizen has the right to obtain employment and a decent living for humanity (Article 27, paragraph 2).

- Maintaining the poor and neglected children (Article 34).

Just to compare with the economic system ala Capitalism, that country generally defined as an economic system in which the commercial economic activity (to seek profit) is done by the state. The production factor is governed and managed as a state enterprise (SOE), or an open company whose controlling shareholder is a state (en: State Holding Enterprise). Many people argue that China's modern economic system is another form of this system, also the former Soviet Union is unwittingly using this system.

The socialist market economy system is an economic system based on the dominance of state-owned sectors in the open market economy. This system is a system used by the state of China and is widely known as another form of the state capitalist system. Slightly different from e systemthe state of capitalism, the factors of production are regulated and managed not only by state enterprises (SOEs) and open companies whose controlling shareholders are state (SHE), but also private companies. The Nordic Model System or also called Nordic Capitalism is an economic system which is a combination of free market capitalism with comprehensive state prosperity and collective bargaining at the national level. This system is used in Nordic countries, namely: Denmark, Finland, Norway, Iceland, and Sweden. Characteristics of the system include:

- A detailed social safety net, coupled with public services such as free education and universal health services

- Strong property rights, contract enforcement, and ease of doing business

- Public pension plans

- Low barriers to free trade

- The lack of regulation of products in the market, etc. The advantages of a mixed economic system include:

- Most businesses and industries can be delivered to private companies that tend to be more efficient than state-controlled companies

- Individual / private rights are clearly recognized

- Economic systems the mix allows government intervention to address problems in free market economies, such as: monopolies, externalities, and public goods

- Mixed economic systems can create equity and provide a "safety net" to prevent people from living in extreme poverty. At the same time, the system can also make people enjoy financial rewards from hard work and entrepreneurship

- The government can create macroeconomic stability with fiscal and monetary policies. The weaknesses of mixed economic systems include:

- It is difficult to know how far governments should intervene in markets and macro economics 
- Mixed economic systems by socialist system experts are perceived as allowing too much market power, causing differences in inequality and inefficient allocation of resources. By the experts of the free market system, the mixed system is considered too much to intervene in the market

- The government is generally a bad economic and business manager, because the government is influenced by political interests and other short-term factors.

As a result, state enterprises become inefficient and the emergence of corruption, collusion, and nepotism The Role of Supervision and Supervision by the Mining Inspector is very large in the management of mineral and coal resources, both on safety, post-regulation in the enactment of Law No.23 The year 2014 did not go well even became a vacuum due to the government budget deficit. The condition of the budget deficit that occurs in the government by the company assesses do not want to know, which is clear if it becomes a rule and stipulated in legislation should be on the run. This opinion is true if in review of aspects of legal benefits such as the rule of law. The law will not be suprem if it is not upheld by people who have power (government) and all its people. B. Policy Forms SOPs, Implementation Procedures, Norms, and CriteriaThe legal basis for the adoption of a policy by government officials is Article 5 and Article 20 of the 1945 Constitution of the State of the Republic of Indonesia. Later it is stipulated by Law Number 30 Year 2014 Administration of Government which aims to: a) Improving the quality of governance, agencies and / or government officials in the use of authority should refer to the general principles of good governance and based on the provisions of legislation. b) Resolve problems in governance, governance arrangements are expected to be a solution in providing legal protection for citizens, communities and government officials; danc) Creating good governance especially for government officials, the law on government administration becomes the legal foundation needed to base the decisions and / or actions of government officials to meet the legal needs of the community in organizing the government. State control over mineral and coal resources by function policy is a series of decisions or government activities designed to address public issues, whether the problem is real or still planned as stated in official documents even in the form of legal regulations directed to the realization of the National objectives of; 1) To protect the entire nation of Indonesia and the entire blood of Indonesia 2) To promote the common prosperity3) To educate the nation, and 4) Participate in world order based on independence, eternal peace and social justice. In order for the management of mineral and coal resources to be managed properly and true, the government sets regulation number 4 of 2009 as a form of implementation of the legislation, then the government regulation is set for the regulation of mineral mining and coal can be implemented. The Government Regulation with the intention is stipulated: 1) Government Regulation No. 23/2010 concerning the Implementation of Mineral and Coal Mining Business Activities, which is subsequently revised by several articles, namely Government Regulation No. 24/2012 on the Implementation of Mining Business Activities and coal. 2) Government Regulation Number 22 Year 2010 regarding Mining Area. 3) Government Regulation No. 55/2010 concerning the fostering and supervision of the management and implementation of mineral and coal mining business; and 4) Government Regulation Number 78 of 2010 on Reclamation and Post-mining. 5) Government Regulation Number 1 Year 2014 on Mineral Processing and Purification Five Government Regulations as a form of implementation technician from Law Number 4 Year 2009 which then by the Minister of Energy and Mineral Resources issued Decree Number 28 of 2009 concerning the Mining and Coal Mining Business . Regulation of Minister of Energy and Mineral Resources No. 07/2012 on Increase of Mineral Added Value through Mineral Processing and Purification Activity, then revised by Minister of Energy and Mineral 
Resources Number 11 Year 2012.In addition to concrete policies through the above-mentioned laws and regulations, the government or state officials authorized to make efforts to realize the welfare of the people and the greatest prosperity of the people as mandated by Article 33 Paragraph (3) of the 1945 Constitution of the Republic of Indonesia, it is stipulated the policy of priority of coal for domestic needs (Domestic Market Oblogation). This means that coal can still be exported when domestic coal needs are met first so that coal becomes more and more as a source of energy for electricity, cement, fertilizer, textile and domestic industries. The policy of prioritizing the fulfillment of coal and minerals for domestic purposes has the main objective of national energy security. Energy is a basic human need that can not be avoided ketnukupannya, and very significantly affect the survival of a nation today and the future. Therefore, national energy security must be achieved, especially those sourced from coal. Furthermore, based on government regulation number 1 of 2014 which requires companies to process and refine mineral in the country. It is necessary to ensure the supply of raw materials for processing and refining facilities to be built, because given the cost of processing and purification machines are quite expensive. In order to overcome and prevent the occurrence of scarcity of mineral and coal supplies, as well as ensure the supply of minerals and coal in the country, it is necessary to apply the priority of the supply of minerals and coal for domestic purposes. Increase in domestic added value can not be separated from the basic characteristics of minerals, ie non-renewable resources. Indeed, it belongs to all the people of Indonesia, therefore the management and utilization must be aimed to increase the added value for the national economy. So the government seeks to implement the increase in added value of minerals. In terms of policy the government has set Presidential Instruction number 3 of 2013 on accelerating the increase of added value of minerals through processing and refining in the country. Based on the above description to increase the contribution of mineral and coal subsectors to the national economy, the Directorate General of Mineral and Coal establishes several policy directions in the development of the mining sector. The policy direction becomes a foothold in the establishment of programs and the sharing of activities in order to encourage the optimization of mineral benefits within the framework of national development, namely: a) implementing mineral and coal fulfillment priorities for domestic needs; b) provide certainty of transparency in mining activities; c) carry out improved supervision and guidance; d) encourage increased investment and state revenues; e) encouraging the development of added value of mining commodity products; and f) maintaining environmental sustainability through environmental management and monitoring including reclamation and post-mining. Implementation of mineral and coal management policies in 2013 is undertaken by: 1 . Encouraging the development of value added commodity products; 2. To carry out improvement of supervision and supervision on mining activities; IUP reconciliation settlement; 4. Completion of renegotiation of amendments to COW and PKP2B; 5.Encourage increased investment and optimization of state revenue through Increased work

Cooperation with relevant agencies (PEMDA, BPK, BPKP, KEMENKEU and KPK); 6. Provide certainty and transparency in mining business activities with regulation supporting Act no. 4 year 2009; and 7. Ensuring domestic coal supply through DMO.Pasca in Law No. 23 of 2014 on regional government, there is a transfer of authority of regency / municipality government to provincial government in this case is the office of the Ministry of Energy and Mineral Resources and Coal (KESDM). At the same time the management of minerba minerals by the provincial government (Governor) followed up by issuing a moratorium on the temporary suspension and immediate dilakukaan arrangement of the licenses of the problem. A qualified license is given a $\mathrm{CnC}$ symbol, for those who qualify for the operation if it has not been given an opportunity to pass the permit and is temporarily categorized as non 
CnC. Actions undertaken by the governor in synergy with the Minister of Energy and Mineral Resources Circular Letter no. 04.E / 30 / DJB / 2015, which stipulates that the Bupati / City shall immediately submit a license file to the Governor. Files in the form of documents that must be submitted are: Furthermore, the Minister of Home Affairs also issued Circular Letter (SE) Minister of Home Affairs no. 120/253 / Sj which is set on 16 January 2015. This Circular Letter is a reference from section 404 of Law no. 23 of 2014, which advocates the immediate transfer of Personnel-Funding-Infrastructure and Equipment-Document (P3D), as a result of the distribution of government affairs between the central government, provincial and regency / municipal areas, which is regulated by this law, 2 (two) years from the date of enactment of this law. With due observance of the provisions of Article 404 above, the budget cycle in APBN and APBD, and to avoid stagnation of local government administration resulting in cessation of services to the public, the implementation of concurrent government affairs that are of service to the public and massive, whose implementation can not be postponed and can be implemented without the support of P3D, still carried out by the level / structure of government which is currently carrying the concurrent government affairs up to the submission of P3D. With the transfer of authority, the district / city is urged so that all documents are also transferred to the provincial government. The file that has been transferred to the province will be followed up by: 1 . Inventory of valid Licensing, while filing and or ending; 2. To inventory regulations and policies related to the EMR field; 3. Preparing ESDM; 4. Technical coordination with the Ministry of Energy and Mineral Resources mineral mining and coal must be in the village properly, because it is a national strategy, if the government does not take the role, it will have a bad impact for the Unitary Republic of Indonesia. Therefore, the programs and activities of the Directorate General of Mineral and Coal should be done based on the mandate of the 1945 Constitution, the Strategic Plan Plan for the subsector of Mineral and Coal. Findings in the field through interviews with the company, especially in PT. Indominco Mandiri located in Bontang Kutai Timur, said that the fulfillment of DMO (Domestic Market Obligation), already implemented, and for coal condition of PT. Indominco Mandiri has a very satisfactory quality and a great selling point to send abroad then the effort made to improve the state's cash income is to sell coal out of the country and the profits are used to buy the type of coal in the DMO to meet domestic needs. Given for the type of coal in need Domestic does not need a high quality. Speaking of mining which is a National Strategy Involvement of PT. Indominco Mandiri to the State is very large, among others, has an obligation to build a sustainable environment by planting trees throughout East Kalimantan and not just the area around the mining of PT Indominco Mandiri in Bontang alone. Similarly, if there is a national disaster PT. Indominco Mandiri also contributed in providing humanitarian assistance call it in 2004 tsunami disaster in Aceh, Lapindo Mud and others, especially if coverage in Bontang area. The efforts of the National strategy undertaken by PT.Indominco Mandiri is certainly in line with the direction of Minerals and Coal Subsector policy. In its implementation, the provincial government of East Kalimantan made a policy by stipulating governor regulation No. 17 of 2015 concerning the arrangement of permits and non-permits as well as improvements to the Licensing Governance in the Mining, Forestry and Oil Palm Plantation sectors. Until now the provincial government of East Kalimantan does not issue a new Mining Business License (IUP) for Minerba mining business activities. Authority issuance of the permit, is on Pro Government of East Kalimantan Province. Given the many problems in the District / City that must be resolved. The problems that exist are not only related to the authority but also related to the problem of work which is also problematic. This is in accordance with Government Regulation No. 23/2010 concerning the Implementation of Minerba Mining Business Activities. In relation to the above governor regulation which is the 
policy or step taken by the Provincial Government to overcome the problems that accumulate. The nature of government policies is: 1) There is a reality or problem that needs to be solved; 2) There is a reason for an action chosen by the government in solving the problem; and 3) There is a correlation between the action and the objectives to be achieved. In relation to state taxes on the management and exploitation of mineral and coal resources, the government policy is public with its implementation to the public, so the role of the community to participate in deciding whether or not to do is necessary to participate. This role can be given directly to the government can also through a representative agency to be channeled to policy makers. The policy of a provision that applies and is characterized by a consistent and repetitive actor, both who make and who obeys it. Public policy is a set of more or less interconnected choices including inaction decisions made by government agencies and agencies. The issue of policy is an urgent thing that is currently hotly discussed, especially in industrial countries such as Indonesia. Policy implementation is not just a mechanism for translating policy objectives in technical and routine procedures but also concerning other factors, especially on resources, relationships between institutional units, levels of government, which may not agree with established policies. This is in line with Rondinell and Cheema's opinion that the relationships between factors affecting policy implementation are: 1) the compliance approach, ie implementation is considered only a technical and routine problem so that the implementation process is pre-determined by political leaders; dan2) The political approach, which is a political approach, views administration as an integral part of the policy-setting process whereby cultivation is modified, redefined and even a heavy burden in the implementation process. According to the authors agree with the views of Rondinell and Cheema, that policy is only seen as a technique and routine and solely an administration will put the policy only within the limits of government decisions established and announced regardless of the extent to which the policy can achieve the desired goals when the policy will taken by the government. Policies that are taken are just formalities that ultimately lead to a policy vulnerable to errors and uncertainties to the community, so that repairs or replacements are made. The authors argue that an ideal policy is a policy that preceded by the participation of the community so that the implementation in line with the interests of the community and will gain public support. In connection with the management and exploitation of mineral and coal resources, should be done with caution because the policy will affect the state revenue for community development. This is an image of government that is responsive to the various aspirations and needs of community development. Besides, it gives direction towards the achievement of the goal of the state that aspires to the welfare of the people.

\section{Conclusion}

The government's policy function on mineral and coal resources in post-regulation stipulates Law no. 23 of 2014 on regional governance which is a legal umbrella for the regulation horizontally related to the environment, forestry and marine sectors. The function of government policy on the aspect of Development and Supervision is not maximal to attribute its duties and functions as it has been fixed in Law no. 4 of 2009 on mineral and coal mining, caused by the limited state budget. Besides, the Legal Certainty System is not yet supremkan so that it can not provide benefits for the needy in this case the entrepreneurs including investors. 


\section{Recommendation}

Soon the government to review the regulation especially the aspects of guidance and supervision to be synergized with the needs of empirical considering the management of mineral and coal resources is the national strategy for post-regulation stipulation Act No. 23 of 2014 on regional governance of Supervision and Supervision by IT not functioning because there is no budget as a means of infrastructure implementation of guidance and supervision. This condition is expected to last long until 2018, the management of mineral and coal mining is in great need of guidance and supervision considering that in the regulation it is explained that the management of minerba is not related to criminal but the function role of IT in empowering for the management of mining can be effective and optimal especially affect the state income, the truth in mining and safety in working in mining.

\section{Reference}

[1]. Dedy, M., 2015, "Ekonomi Kerakyatan, dari Bung Hatta sampai Jokowi?," Badan Pusat Statistik Provinsi Sumatera Selatan, http://sumsel.bps.go.id/KegiatanLain/view/id/10 (diakses 1 November 2017).

[2]. Eko, Y., 2009, "Mengidentifikasi Sistem Ekonomi, Untuk Memecahkan Masalah Ekonomi," Ekonomi 1 : Untuk SMA dan MA Kelas X, Pusat Perbukuan, Departemen Pendidikan Nasional, Jakarta

[3]. Mulyati, E., 2009, "Ekonomi Kerakyatan," staff.uny.ac.id, http://staff.uny.ac.id/sites/default/files/pendidikan/Dr.\%20Endang\%20Mulyani,\%20M.Si./EKORA \%20-\%20Hakekat\%20EKORA.pdf (diakses 1 November 2017).

[4]. Peter Marzuki, 2009., Penelitian Hukum Edisi revisi, Jakarta.

[5]. Pettinger, T., 2012, "Mixed economy," EconomicsHelp.org, http://www.economicshelp.org/blog/glossary/mixed-economy/ (diakses 11 November 2016)

[6]. Roni Hanitijo Soemitro, Metodologi Penelitian Hukum dan Jurimetri, (Penerbit Ghalia Indonesia Jakarta, 1998).

[7]. Samuelson \& Nordhaus, 2009, "Market, Command, and Mixed Economies," Economics, 19th edition, McGraw-Hill, New York, NY.

[8]. Sentosa Sembiring, 2007, Hukum Penanaman modal , Pembahasan Dilengkapi Dengan UndangUndang Nomor 25 Tahun 2007 tentang Penanaman Modal, CV. Nuansa Aulia, Bandung,

[9]. Suryaningsi, 2017, Eksistensi Negara atas Pengelolaan dan Pengusahaan Sumber daya Mineral dan Batubara, Penerbit Total Media, Jogyakarta.

[10]. Wikipedia contributors, "State capitalism," Wikipedia, The Free Encyclopedia, https://en.wikipedia.org/w/index.php?title=State_capitalism\&oldid=740732132 (diakses November 2017).

[11]. Wikipedia contributors, "Socialist market economy," Wikipedia, The Free Encyclopedia, https://en.wikipedia.org/w/index.php?title=Socialist_market_economy\&oldid=745434288 (diakses 1 November 2017).

[12]. Wikipedia contributors, "Nordic model," Wikipedia, The Free Encyclopedia, https://en.wikipedia.org/w/index.php?title=Nordic_model\&oldid=748568773 (diakses 1 November 2017). 